\title{
PENGUJIAN EFEKTIVITAS CAPSICUM SEBAGAI SUMBER CAPSAICIN KO-ANESTESI PADA ANESTESI LOKAL
}

\author{
Aldian Mulyanto Lokaria ${ }^{1}$, Muhammad Ridwan ${ }^{1}$, Muhamad Febry ${ }^{1}$, Fadil Oenzil²
}

\begin{abstract}
Abstrak
Anestesi lokal bekerja dengan memblok sel saraf sensorik rasa sakit (nosiseptor) dan sel saraf lain, sehingga diperlukan Capsaicin pada cabai sebagai ko-anestesi agar obat anestesi lokal bekerja spesifik pada nosiseptor. Beragam varietas cabai menuntut adanya penelitian untuk mengetahui jenis cabai yang tepat sebagai sumber Capsaicin ko-anestesi, hubungan dengan peningkaan kadar Capsaicin, dan pengaruh terhadap waktu kerja obat anestesi. Penelitian ini merupakan penelitian eksperimental dengan desain pre and post test design. Penelitian dilakukan di Laboratorium Biota Sumatera Universitas Andalas dan di Laboratorium Hewan Fakultas Kedokteran Unand selama 3 bulan. Sampel penelitian ini adalah tikus (Rattus novergicus) jantan dari galur Sprague Dawley dengan berat 250-350 gram, sebanyak 24 ekor dibagi 8 kelompok. Tiap kelompok mendapatkan perlakuan berupa pemberian Capsaicin dari jenis cabai dengan kadar yang berbeda. Hasil penelitian terdapat perbedaan waktu munculnya efek sensorik $(p 0,020)$ dan motorik ( $p 0,001)$ antar kelompok perlakuan. Kelompok C.frutescens $5 \%$ tercepat dalam menghentikan bloking saraf motorik (3,33 menit), sedangkan kelompok C.frutescens $10 \%$ terbaik dalam mempengaruhi lama bloking saraf sensorik (53,67 menit). Dimana peningkatan kadar berbanding lurus dengan hasil anestesi dan jenis cabai dengan kadar yang berbeda juga mempengaruhi lama waktu kerja obat anestesi.
\end{abstract}

Kata kunci: Anestesi Lokal, Capsaicin, Ko-anestesi

\begin{abstract}
Local anesthesia works by blocking pain sensory nerve cells (nociceptors) and other nerve cells, it's need capsaicin in chili as co-anesthesia so that local anesthesia specific work on nociceptors only. The diversity of chili, demand more research to determine the most appropriate type of chili as a source of capsaicin co-anesthesia. This is a pre and post test design experimental research. Which each groups is given of Capsaicin from different chili types and concentration. There are difference time in emergence of sensory effects ( $p$ 0.020) and motor effects ( $p$ 0.001) between groups. Group of C.frutescens $5 \%$ is the fastest group in stopping of the motor nerve blocking (3.33 minutes), while group of C.frutescens $10 \%$ is best group in influencing long-blocking sensory nerves (53.67 minutes). Thus the increased concentration is linear correlation to the results of anesthesia and the types of chili with different concentration affect the work time of anesthesia.
\end{abstract}

Keywords: Local Anesthesia, Capsaicin, Co-anesthesia

Afiliasi Penulis : 1. Fakultas Kedokteran Universitas Andalas 2. Bagian Biokimia Fakultas Kedokteran Universitas Andalas, Korespondensi : Muhamad Febry, Febry_be@yahoo.com.com,Telp: 085378252802 


\section{PENDAHULUAN}

Istilah anestesi menggambarkan keadaan tidak sadar yang bersifat sementara ${ }^{1}$. Anestesi lokal sendiri adalah tindakan pemberian obat yang mampu menghambat konduksi saraf secara reversibel pada bagian tubuh yang spesifik dan bersifat setempat ${ }^{2}$.

Beragam jenis obat anestesi lokal yang digunakan seperti prokain, lidokain, ropivakain, dan bupivakain. Obat ini bekerja dengan cara memblok sel saraf sensorik sehingga bagian tubuh yang dikenainya tidak dapat menghantarkan impuls rasa sakit ${ }^{1}$. Obat anestesi lokal pada konsentrasi tertentu tidak hanya memblok sel saraf rasa sakit (nosiseptor) namun ikut memblok sel saraf sensorik lain dan menyebabkan mati rasa ${ }^{3}$. Obat anestesi lokal juga dapat memblok sel saraf motorik sehingga menyebabkan kekakuan pada otot yang dipersarafinya. Untuk mengatasi permasalahan ini maka dikembangkan suatu prinsip anestesi lokal baru dimana anestesi lokal yang digunakan memblok sel saraf sensorik yang hanya mengantarkan impuls rasa sakit, yakni dengan cara memberi zat-zat tambahan (ko-anestesi) agar dapat bekerja secara ${ }^{4}$. Salah satu zat ko-anestesi tersebut adalah capsaicin yang terdapat pada cabai (Capsicum) ${ }^{5}$. Nosiseptor ini terdapat saluran Transient Receptor Potential Vanilloid 1 (TRPV1) sebagai transduser termosensitif yang dapat diaktivasi oleh sifat panas (iritan) pada capsaicin, sedangkan pada sel saraf lain saluran TRPV1 ini tidak diekspresikan ${ }^{6}$. Hal inilah yang yang menyebabkan capsaicin bersifat spesifik ${ }^{7}$.

Capsaicin merupakan komponen aktif cabai yang bersifat iritan ${ }^{8}$. Peter, et al., (2009) mengkombinasikan pemakai- an capsaicin dengan beragam obat anestesi lokal seperti lidokain, bupivakain, amitriptyline, dan amphipathic $N$ methyl amitriptyline pada tikus ${ }^{9}$. Dalam penerapannya penggunaan cabai yang tepat menjadi sangat penting, terutama dari beragam jenis cabai yang ada serta perbedaan kandungan capsaicin. Perlu dilakukan suatu penelitian lebih lanjut untuk membuktikan jenis cabai yang paling tepat sebagai capsaicin.

\section{METODE}

Penelitian ini merupakan penelitian eksperimental laboratorium dengan pre and post test design. Sampel pada penelitian ini dibagi kedalam 8 kelompok secara acak dan tertutup, dimana setiap kelompok akan mendapatkan perlakuan berbeda berupa pemberian capsaicin dari jenis ekstrak biji cabai yang berbeda dan kadar yang berbeda pula.

Tempat pembuatan ekstrak biji cabai dilakukan di Laboratorium Biota SumateraUniversitas Andalas, pengujian terhadap sampel di Laboratorium Hewan Fakultas Kedokteran Unand. Penelitian dilakukan selama 3 bulan. Tikus (Rattus novergicus) jantan dari galur Sprague Dawley dengan berat 250-350 gram tiap ekornya digunakan dalam penelitian ini. Jumlah total sampel yang dibutuhkan dalam penelitian ini sebanyak 24 ekor tikus untuk delapan kelompok atau tiga ekor tiap kelompok ${ }^{10}$. Sebelum perlakuan, sampel diadaptasi selama 1 minggu, serta dipuasakan selama dua belas jam sebelum diberikan perlakuan.

Alat yang digunakan berupa gelas ukur, bejana maserasi, aluminium foil, rotary evaporator, handscoen, spuit, kapas steril, dan stopwatch. Sedangkan bahan habis pakai pada penelitian ini 
berupa cabai rawit (C. frutescens), cabai keriting (C.annuum), cabai merah keriting (C.annuum var.frutescens), dan cabai hijau (C.annuum var.longum), etanol 96\%, aqua pro injection, filter paper, serta lidokain.

Masing-masing jenis cabai sebanyak $2 \mathrm{~kg}$ dibersihkan dengan mengambil bijinya saja. Biji cabai kemudian dikeringkan dan dihaluskan. Bahan aktif (Capsaicin) dari biji cabai selanjutnya diekstraksi secara maserasi menggunakan pelarut etanol $96 \%$ dengan perbandingan 6 bagian pelarut dalam mililiter untuk tiap satu bagian simplisia dalam gram. Maserasi dilakukan sebanyak dua kali menggunakan simplisia yang sama dalam waktu selama tiga hari untuk tiap kali maserasinya. Hasil maserasi baik yang pertama maupun yang kedua kemudian diekstraksi. Dimana kadar Capsaicin terlarut dapat diperoleh dengan mengalikan ekstrak biji cabai murni yang didapat dengan rasio Capsaicin per Dihydrocapsaicin masing-masing jenis cabai. Ekstrak biji cabai yang mengandung Capsaicin dari keempat jenis biji cabai tersebut kemudian dilarutkan dengan aqua pro injection untuk membuat 4 jenis larutan Capsaicin. Larutan Capsaicin ini dilarutkan dalam 2 kadar yaitu 5\% dan $10 \%$ sehingga diperoleh 8 kelompok larutan Capsaicin.

Sesuai dengan penelitian yang dilakuan Peter et al., (2009) maka penggunaan lidokain sebagai obat anestesi lokal pada sampel berupa tikus (Rattus novergicus) jantan dari galur Sprague Dawley dengan berat 250-350 gram tiap ekornya ditetapkan sebanyak 0,2 $\mathrm{ml}^{9}$. Larutan Capsaicin sebagai ko-anestesi lokal yang akan diberikan secara terpisah sebanyak 0,1 ml setiap kelompok. Injeksi 0,2 ml lidokain pada regional kaki belakang tikus secara intramuskuler. Lima menit kemudian, injeksikan larutan Capsaicin pada ke-8 kelompok, dimana untuk setiap sampel mendapatkan $0,1 \mathrm{ml}$ larutan Capsaicin.

Dari data yang diperoleh hitung waktu kerja rata-rata obat anestesi lokal pada masing-masing kelompok tikus, di menit ke berapa sampel mulai memberikan refleks gerak bila diberikan rangsangan nyeri berupa tusukan, dan pada menit ke berapa regional belakang kaki tikus yang dianestesi mulai dapat digerakan secara normall11,12. Kelompok tikus yang menunjukan gerak motorik dalam menit tercepat dan dengan gerak refleks terjadi pada menit terlama menunjukkan jenis obat anestesi lokal yang digunakan memiliki efek menghentikan blok sel saraf motorik tercepat dan efek memblok sel saraf sensori rasa sakit yang lebih lama, sehingga lebih disarankan untuk diterapkan.

\section{HASIL DAN PEMBAHASAN}

Dari masing-masing $2 \mathrm{~kg}$ cabai merah keriting, cabai merah, cabai hijau, dan cabai rawit, dihasilkan simplisia berupa biji cabai halus dengan jumlah yang berbeda. Tabel 1 dapat dilihat bahwa biji cabai yang dihasilkan dari cabai merah keriting memiliki berat terbesar dibandingkan jenis cabai lain. Konsentrasi biji cabai halus dibandingkan dengan beratawalnya dapat diketahui dengan cara membagi jumlah berat biji cabai halus dengan berat cabai utuh pada mulanya. Hasil yang didapatkan cabai merah keriting memiliki kadar biji cabai halus tertinggi yaitu 0,056 . Diikuti cabai merah 0,047 serta cabai hijau dan cabai rawit dengan kadar yang sama 0,017. 
Tabel 1. Hasil Ekstraksi Biji Cabai

\begin{tabular}{|c|c|c|c|}
\hline $\begin{array}{l}\text { Jenis } \\
\text { Cabai }\end{array}$ & $\begin{array}{c}\text { Berat biji } \\
\text { Cabai } \\
\text { Halus } \\
\text { (gr) }\end{array}$ & $\begin{array}{c}\text { Volume } \\
\text { Ekstrak } \\
\text { Biji Cabai } \\
\text { (ml) }\end{array}$ & $\begin{array}{c}\text { Persentase } \\
\text { Kadar Zat } \\
\text { Aktif } \mathrm{ml} / \mathrm{mg} \\
(\%)\end{array}$ \\
\hline $\begin{array}{l}\text { Cabai } \\
\text { Merah } \\
\text { Keriting }\end{array}$ & 112 & 9,42 & 8,41 \\
\hline $\begin{array}{l}\text { Cabai } \\
\text { Merah }\end{array}$ & 94 & 3,48 & 3,70 \\
\hline $\begin{array}{l}\text { Cabai } \\
\text { Hijau }\end{array}$ & 33 & 1,60 & 4,85 \\
\hline $\begin{array}{l}\text { Cabai } \\
\text { Rawit }\end{array}$ & 33 & 3,74 & 11,33 \\
\hline
\end{tabular}

Proses maserasi baik yang pertama maupun yang kedua serta proses ekstraksi, dilihat pada tabel 1 yaitu volume ekstrak biji cabai murni untuk masing-masing jenisnya. Pada ekstrak biji cabai murni terkandung Capsaicinoid dengan komponen utama Capsaicin dan Dihydrocapsaicin dengan perbandingan kadar yang berbeda tergantung jenis cabai yang digunakan. Penelitian yang telah dilakukan Sukrasno (1997), perbandingan kadar zat aktif yang berbeda menghasilkan persentase kadar zat aktif dalam biji cabai yang berbeda pula untuk setiap jenis biji cabai yang digunakan ${ }^{13}$. Persentase kadar zat aktif yang terdapat dalam biji cabai didapati dengam membagi kadar zat aktif atau volume hasil ekstraksi dalam mililiter dengan berat biji cabai awal yang digunakan, dimana persentase kadar tertinggi dipegang oleh jenis cabai rawit dengan persentase $11,33 \%$ zat aktif untuk setiap bobot biji cabai kering. Hal ini sesuai dengan hasil penelitian yang dilakukan Sukrasno (1997), yaitu kadar Capsaicin per bobot kering biji cabai terbesar terdapat pada jenis cabe rawit. ${ }^{13}$

Tabel 2 dan 3 menunjukan hasil evaluasi terhadap pemberian lidokain disertai larutan Capsaicin sebagai koanestesi. Efek motorik dinilai sudah aktif bila telah tidak ada keabnormalan lagi pada gerak motorik di regional kaki belakang sampel yang dibius. Efek sensorik dinilai sudah aktif bila sampel memberikan gerak refleks saat diberikan rangsangan nyeri.

Tabel 2. Evaluasi Fungsi Motorik Aktif

\begin{tabular}{lccc}
\hline \multirow{2}{*}{ Kelompok } & \multicolumn{3}{c}{ Efek motorik aktif (menit) } \\
\cline { 2 - 4 } & Sampel 1 & Sampel 2 & Sampel 3 \\
\hline MK 5\% & $32^{\prime}$ & $32^{\prime}$ & $31^{\prime}$ \\
MK 10\% & $23^{\prime}$ & $30^{\prime}$ & $30^{\prime}$ \\
M 5\% & $2^{\prime}$ & $20^{\prime}$ & $20^{\prime}$ \\
M 10\% & $0^{\prime}$ & $23^{\prime}$ & $28^{\prime}$ \\
H 5\% & $44^{\prime}$ & $78^{\prime}$ & $80^{\prime}$ \\
H 10\% & $16^{\prime}$ & $60^{\prime}$ & $74^{\prime}$ \\
R 5\% & $0^{\prime}$ & $0^{\prime}$ & $10^{\prime}$ \\
R 10\% & $5^{\prime}$ & $17^{\prime}$ & $31^{\prime}$ \\
\hline
\end{tabular}

Tabel 3. Evaluasi Fungsi Sensorik Aktif

\begin{tabular}{lccc}
\hline \multirow{2}{*}{ Kelompok } & \multicolumn{3}{c}{ Efek sensorik akif (menit) } \\
\cline { 2 - 4 } & Sampel 1 & Sampel 2 & Sampel 3 \\
\hline MK 5\% & $49^{\prime}$ & $51^{\prime}$ & $50^{\prime}$ \\
\hline MK 10\% & $52^{\prime}$ & $52^{\prime}$ & $52^{\prime}$ \\
\hline M 5\% & $24^{\prime}$ & $31^{\prime}$ & $34^{\prime}$ \\
\hline M 10\% & $24^{\prime}$ & $31^{\prime}$ & $32^{\prime}$ \\
\hline H 5\% & $48^{\prime}$ & $42^{\prime}$ & $66^{\prime}$ \\
\hline H 10\% & $56^{\prime}$ & $46^{\prime}$ & $56^{\prime}$ \\
\hline R 5\% & $40^{\prime}$ & $50^{\prime}$ & 59 \\
\hline R 10\% & $40^{\prime}$ & $58^{\prime}$ & $63^{\prime}$ \\
\hline
\end{tabular}

Keterangan kelompok perlakuan:

MK 5\%: larutan Capsaicin terlarut 5\% dari cabai merah keriting

MK 10\%: larutan Capsaicin terlarut 10\% dari cabai merah keriting

M 5\%: larutan Capsaicin terlarut 5\% dari cabai merah M 10\%: larutan Capsaicin terlarut 10\% dari cabai merah

H 5\%: larutan Capsaicin terlarut 5\% dari cabai hijau H 10\%: larutan Capsaicin terlarut $10 \%$ dari cabai hijau R 5\%: larutan Capsaicin terlarut 5\% dari cabai rawit R 10\%: larutan Capsaicin terlarut $10 \%$ dari cabai rawit 
Dari data tabel 3 dan 4 didapat lama waktu kerja lidokain. Lama waktu kerja lidokain sebuah kelompok diambil dengan cara mencari waktu pengaktifan fungsi sensorik atau motorik terlama pada satu sampel dibandingkan sampel lainnya dalam satu kelompok. Kelompok $\mathrm{H} 5 \%$ adalah urutan pertama dengan waktu kerja lidokain terlama, sedangkan lama waktu kerja tercepat terjadi pada kelompok M 10\%.

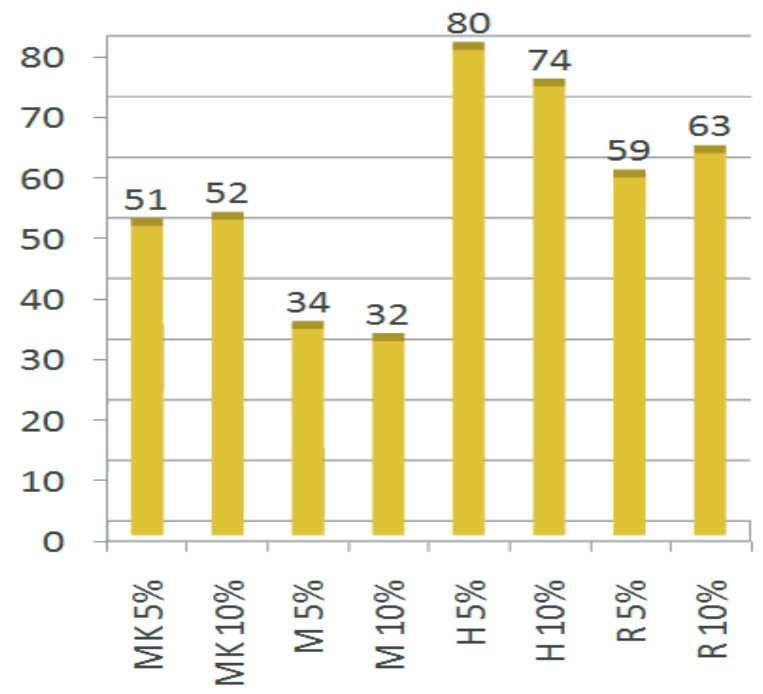

Diagram 1. Waktu Kerja Lidokain (Menit)

Penelitian yang dilakukan Ari (2007), lama waktu kerja lidokain normalnya berkisar antara 45 menit hingga 90 menit. Sesuai dengan pernyataan tersebut, maka terdapat 6 kelompok dari 3 jenis cabai di Diagram 1 yang menyebabkan lidokain bekerja sesuai dengan waktu kerja normal ${ }^{14}$. Ketiga jenis cabai tersebut bila diurutkan sesuai dengan urutan 3 besar berdasarkan banyaknya kadar Capsaicin terlarut yang diterima sampel (lihat Tabel 2), sehingga dapat ditarik kesimpulan bahwa Capsaicin berperan pula dalam mempercepat lama waktu kerja obat anestesi lokal yang digunakan.

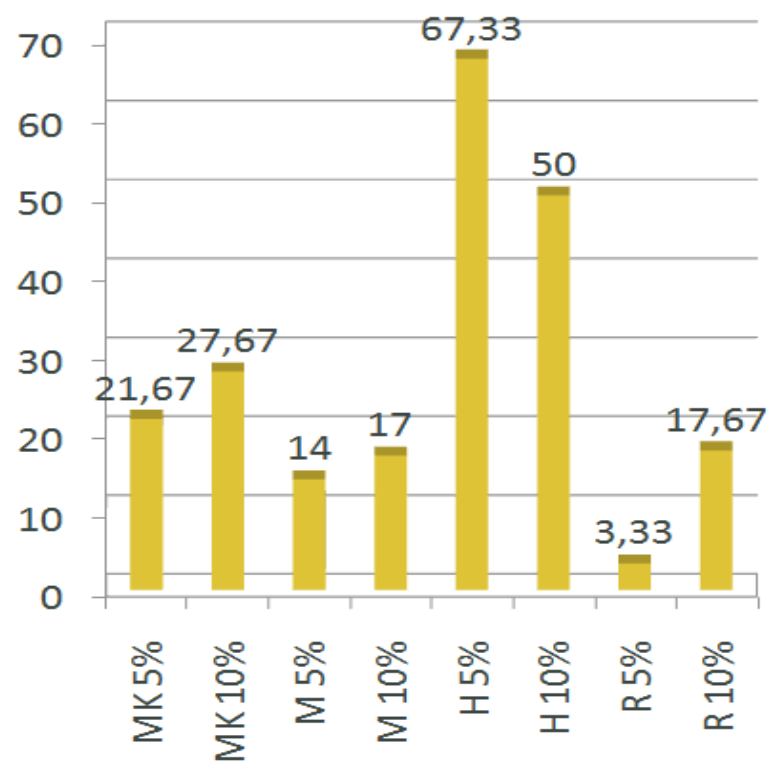

Diagram 2. Rata-rata Waktu Efek Motorik Aktif (menit)

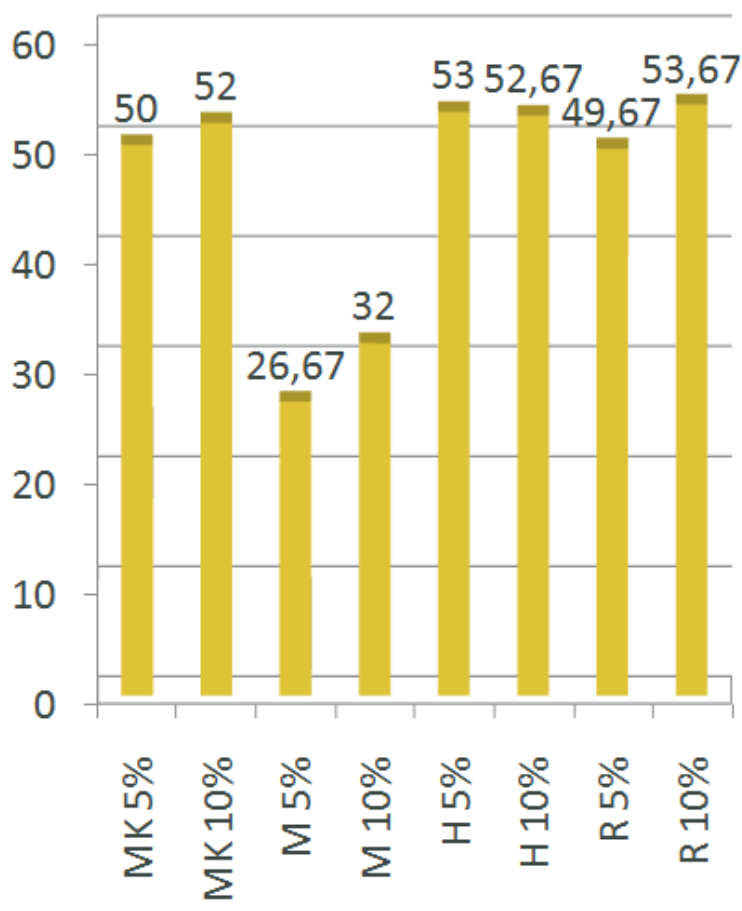

Diagram 3. Rata-rata Waktu Efek Sensorik Aktif (menit)

Diagram 2 dan 3 menggambarkan hasil pemberian lidokain dan larutan Capsaicin di regional kaki belakang sampel, yang diamati dari efek motorik dan sensori. Hasil terbaik dinilai dari cepatnya waktu blokade fungsi motorik sampel diraih oleh kelompok R 5\%. Efek 
motorik sudah benar-benar muncul dalam waktu kurang dari empat menit padahal fungsi sensorik (rasa nyeri) belum bekerja, hal ini sesuai dengan hasil penelitian yang dilakukan Peter, et all., (2009) berkenaan dengan fungsi Capsaicin yang membuat lidokain menjadi spesifik, dimana hanya memblok saraf sensorik rasa nyeri (nosiseptor) dan tidak memblok saraf sensorik maupun motorik lainnya ${ }^{9}$. Hal ini dapat terjadi karena jumlah Capsaicin terlarut lebih besar daripada yang terdapat pada jenis cabai merah dan cabai hijau.

Tabel 5. Konsentrasi Capsaicin Terlarut dalam Ekstrak Cabai Murni

\begin{tabular}{lccc}
\hline Kelompok & $\begin{array}{c}\text { Ekstra } \\
\text { k biji } \\
\text { cabai }\end{array}$ & $\begin{array}{c}\text { Capsaicin } \\
\text { /Dihydro } \\
\text { capsaicin }\end{array}$ & $\begin{array}{c}\text { Capsaici } \\
\mathbf{n} \text { terlarut }\end{array}$ \\
\hline $\begin{array}{l}\text { Cabai } \\
\text { merah }\end{array}$ & $9,42 \mathrm{ml}$ & 1,704 & $5,94 \mathrm{ml}$ \\
$\begin{array}{l}\text { keriting } \\
\text { Cabai } \\
\text { merah }\end{array}$ & $3,48 \mathrm{ml}$ & 2,417 & $2,46 \mathrm{ml}$ \\
$\begin{array}{l}\text { Cabai hijau } \\
\text { Cabai rawit }\end{array}$ & $1,60 \mathrm{ml}$ & $\begin{array}{c}\text { Hanya } \\
\text { capsaicin } \\
2,74 \mathrm{ml}\end{array}$ & $1,60 \mathrm{ml}$ \\
\hline
\end{tabular}

Berdasarkan penelitian yang dilakukan Sukrasno, dkk (1997), didapatkan rasio Capsaicin per Dyhidrocapsaicin seperti yang terdapat pada tabel 5, sehingga kita bisa mendapatkan kadar Capsaicin terlarut pada ekstrak biji cabai murni ${ }^{7}$. Kadar Dyhidrocapsaicin terlarut didapatkan dengan mengurangi volume ekstrak biji cabai murni dengan jumlah Capsaicin terlarut. Dengan kadar Dyhidrocapsaicin ini perbedaan hasil yang konsisten pada kelompok cabai konsentrasi $5 \%$ dengan $10 \%$ pada jenis cabai yang sama dapat dijelaskan. Kelompok cabai konsentrasi 5\% memiliki waktu aktif efek motorik yang lebih cepat dikarenakan kadar dihydrocapsaicin yang dimiliki lebih kecil dibandingkan dengan kelompok cabai sejenis pada konsentrasi $10 \%$, terkecuali untuk kelompok cabai hijau yang tidak memiliki kandungan Dihydrocapsaicin ${ }^{5}$.

Bila dinilai dari lamanya waktu blokade fungsi sensorik sampel, hasil terbaik adalah kelompok R $10 \%$. Bila dibandingkan antara kelompok dari sumber cabai sejenis, tidak seperti pada efek motorik, perbedaan konsentrasi Capsaicin tidak terlalu menyebabkan perbedaan yang jauh antara kelompok dengan konsentrasi capsaicin terlarut $5 \%$ dan $10 \%$. Hal ini menandakan untuk blokade fungsi sensorik sampel tidak terlalu dipengaruhi adanya Dihydrocapsaicin pada kelompok cabai sejenis. Sementara hasil terburuk dinilai dari cepatnya waktu blokade fungsi sensorik sampel diraih oleh kelompok $M 5 \%$. Dimana cabai dari kelompok ini memiliki kadar Capsaicin terlarut yang terendah dibandingkan kelompok cabai merah keriting dan cabai rawit. Sedangkan bila dibandingkan dengan kelompok cabai hijau yang memiliki waktu blokade sensorik yang lebih lama, hal ini diakibatkan hampir sepertiga komponen zat aktif kelompok cabai merah adalah Dihydrocapsaicin, sedangkan tidak ada sama sekali pada kelompok cabai hijau ${ }^{5}$.

Analisis bivariat yang dilakukan untuk mengetahui adanya perbedaan efek anestesi lokal pemberian Capsaicin dari ekstrak biji Capsicum dengan jenis dan kadar berbeda, sehubungan dengan fungsinya sebagai ko-anestesi lokal didapatkan nilai (p) 0,020 (p<0,05) untuk efek sensorik, sehingga dapat disimpulkan terdapat perbedaan waktu munculnya efek sensorik yang bermak- 
na antar kelompok perlakuan. Penelitian ini juga didapatkan nilai (p) 0,001 ( $p<$ 0,05 ) untuk efek motorik, sehingga dapat disimpulkan terdapat perbedaan waktu munculnya efek motorik yang bermakna antar kelompok perlakuan.

\section{SIMPULAN}

Kelompok cabai rawit dengan konsentrasi 5\% menjadi kelompok terbaik dalam mempersingkat bloking saraf motorik, yakni membuat bloking saraf motorik hanya berlangsung selama 3,33 menit, sehingga otot dapat segera digerakkan meskipun dalam keadaan dibius. Sedangkan kelompok cabai rawit

\section{DAFTAR RUJUKAN}

1. Latief S, Surjadi K, Dachlan R. Anestetik Lokal Dalam: Petunjuk Praktis Aneste-siologi. Jakarta: Bagian Anestesiologi dan Terapi Intensif Fakultas Kedokteran Universitas Indonesia, 2001.

2. Morgan GE, Mikhail MS, Murray MJ. Local anesthetics In: Clinical Anesthesiology $4^{\text {th }}$ ed. New York: Mc Graw Hill Lange Medical Books, 2006.

3. Ratno S, Doso S, Hari HS. Mekanisme kerja obat anestesi lokal. J Anestesiol Indonesia 2011;3(1):48-59.

4. Lim TK, Macleod BA, Ries CR, Schwarz SK. The quaternary lidocaine derivative, QX-314, produces longlasting local anesthesia in animal models in vivo. Anestesiol 2007;107(1):305-11.

5. Binshtok AM, Peter G, Seog BO, Michelino P, Suzuko S, David PR, Teri H, Chi FW, onghoon K, Gehoon C, Aya AM, Ging KW, Bean BP, Woolf CJ. Coapplication of lidocaine and the permanently charged sodium channel blocker QX-314 produces a long lasting Nociceptive Blockade in Rodents. Anesthesiol 2009;111(1):127-37.

6. Immke DC, Gavva NR. The TRPV1 receptor and nociception. Semin Cell Dev Biol 2006; 17(1):582-591.

7. Knotkova H, Pappagallo M, Szallasi A. Capsaicin (TRPV1 agonist) therapy for pain dengan konsentrasi 10\% menjadi kelompok terbaik dengan bloking saraf sensorik terlama, yakni dapat membuat bloking saraf sensorik hingga 53,67 menit.

Dari penelitian ini didapatkan nilai (p) 0,020 untuk munculnya efek sensorik dan (p) 0,001 untuk munculnya efek motorik yang menandakan kebermaknaan antar kelompok perlakuan. Berdasarkan lama waktu kerja lidokain normal, pemberian capsaicin dari kelompok ekstrak biji cabai merah keriting, hijau, dan rawit tidak terlalu mempengaruhi lama waktu kerja lidokain normal.

relief: Farewell or revival. Clin $J$ Pain 2008;24(1):142-54.

8. Ismanik JF. Studi tingkat kepedasan Capcaisinoid pada biji Capsicum Annuum dalam Ekstrak Etanol Menggunakan Metode Voltametri Siklik. ITS: Surabaya; 2011.

9. Peter G, Binshtok AM, Chi FW, Hevelone ND, Bean BP, Woolf CJ, et al. Capsaicin combined with local anesthetics prefe-rentially prolongs sensory/ nociceptive block in Rat sciatic nerve. Anesthesiol 2009;109(5):872-8.

10.Supranto J. 2000. Statistik: Teori dan aplikasi. Jakarta: Erlangga:43-57.

11. Hesti P, Shanti L, Tetri W. Aktivitas Analgetik ekstrak umbi teki (Cyperus rotundusL.) pada Mencit Putih (Mus musculusL.) jantan. Biofarmasi 2003;1(2): 50-7.

12.Andreanus A. Soemardji, Endang K,Cucu A. Toksisitas Akut dan Penentuan $\mathrm{DL}_{50}$ Oral Ekstrak Air Daun Gandarusa (Justicia gendarussa Burm F.) pada Mencit Swiss Webster. JMS 2002 7(2)57-62.

13.Sukrasno, Siti K, Tarini S, Sasanti NC, Sugiarso. Kandungan kapsaisin dan dehidro kapsaisin pada berbagai buah capsicum. JMS 1997;2(1):28-34.

14. Ari E, Azalia A. Farmakologi dan terapi. Departemen Farmakologi dan Terapeutik FKUI:Jakarta;2007. 